\title{
Participatory ergonomics and new work: reducing neck complaints in assembling
}

\author{
S.A. Miguez ${ }^{a}$, M.S. Hallbeck ${ }^{b}$ P. Vink $^{c}$ \\ ${ }^{a}$ Ergosys Consulting, Brazil \\ ${ }^{\mathrm{b}}$ University of Nebraska-Lincoln, Industrial and Management Systems Engineering, Lincoln, NE, USA \\ ${ }^{\mathrm{c}}$ Faculty of Industrial Design Engineering, Delft University of Technology, Landbergstraat 15, 2628 CE Delft, \\ The Netherlands
}

\begin{abstract}
A participatory ergonomics approach is used to create a new work environment, which is aimed at reducing neck complaints in a cell phone assembly. The participatory ergonomics program included an initiative, problem identification, a selection of solutions, an implementation and evaluation. Twenty-eight women, all operators on an assembly line of cell phone boards, voluntarily participated in the design and evaluation of a device before implementing the device to all 215 employees performing that job. Prior to and after the intervention, RULA, comfort experiences and interviews were used. After introducing an adjustable angled small counter, these measurements showed both posture and comfort improvements. $90 \%$ of the 215 workers preferred the new work station and the neck complaints were reduced in $75 \%$ of the group. It also showed that the initial prototype needed to be modified as to reduce its sharp edges/compression points for the forearm. This project shows the importance of iterative testing and that an initiative by workers enlarges the chance of successful implementation.
\end{abstract}

Keywords: participatory ergonomics, new work, neck complaints, assembly, comfort.

\section{Introduction}

Work-related musculoskeletal disorders are often found among industrial workers and they contribute considerably to absenteeism [10]. Light assembly work is a clear example of low-intensity work with elevated risks of neck and shoulder disorders [1]. There are indications that a participatory ergonomics approach leads to improvements [9]. Therefore, in this case this participatory approach has been applied to assembly work: assembling cell phones.

The cell phone industry currently faces challenges such as high quality manufacturing, market competition and constant technological innovation. These challenges, in turn, force the sector to continuously alter its production process. These changes are demanding because the industry also needs to incorporate the quality of life for workers in the company. Implementation of ergonomic improvements can be difficult, but an approach showing successes is participatory ergonomics [9]. Therefore participatory ergonomics was the strategy used for the development of an ergonomic intervention in cell phone assembly. The core of the approach is the involvement of people from different company areas for the fostering of general acceptance (buy-in) and direct participation in solving problems

The demand for this study (neck pain) arose from the workers themselves during the ergonomic evaluation carried out by the company's ergonomist. This preliminary study aimed to develop an ergonomic device, which we called a "small counter", which was based on the user's need and improved iteratively using participatory ergonomic processes. This process resulted in the development of two prototypes before the final version was designed. The final version will be manufactured by an outsourced company and implemented in the focused company.

\section{Methods}

\subsection{Subjects}

Twenty-eight (28) female operators on the assembly line of cell phone boards, between 20 and 37 years of age, between 5'0.6' ' and 5'8', (153.7 to 173 $\mathrm{cm})$ tall and with middle school or better education 
voluntarily participated in this study. The participants all worked in fixed shifts of 8 hours a day, from Monday through Friday.

\subsection{Instruments}

Ergonomic analysis of the task was done through direct observation of postures, unstructured interviews with the workers, and photographs for later evaluation techniques such as RULA (Rapid Upper Limb Assessment).

Comparisons of data before and after the ergonomic intervention were done through RULA, which is "a screening tool that assesses biomechanical and postural loading on the whole body with particular attention to the neck, trunk and upper limbs" [3]. RULA values range from 1 to 7 and they define the action level to be taken, as is shown in table 1:

Table 1

RULA's action level [3]

\begin{tabular}{|l|l|}
\hline \multicolumn{2}{|c|}{ RULA's action level [3] } \\
\hline Action Level & \multicolumn{1}{c|}{ Results } \\
\hline Action Level 1 & $\begin{array}{l}\text { A score of } \text { one } \text { or } \text { two } \text { indicates that pos- } \\
\text { ture is acceptable if it is not maintained or } \\
\text { repeated for long periods of time. }\end{array}$ \\
\hline Action Level 2 & $\begin{array}{l}\text { A score of three or four indicates that } \\
\text { further investigation is needed and changes } \\
\text { may be required. }\end{array}$ \\
\hline Action Level 3 & $\begin{array}{l}\text { A score of five } \text { or six indicates investiga- } \\
\text { tion and changes are required soon. }\end{array}$ \\
\hline Action Level 4 & $\begin{array}{l}\text { A score of seven } \text { or more indicates inves- } \\
\text { tigation and changes are required immedi- } \\
\text { ately. }\end{array}$ \\
\hline
\end{tabular}

\subsection{Description of the activity before intervention}

Cell phone board assembly consists of visual inspection, manual insertion of components on the board, board positioning on the jig and soldering of the components using a soldering iron. The work is performed on a horizontal counter which is height adjustable, and the worker statically stands on an anti-fatigue mat. The cycle time of the activity varies according to the cell phone model and the demand of production of the day, alternating between short cycles (less than 30 seconds) and long cycles (greater than 30 seconds) over an 8-hour day.

The production layout consists of parallel workstations, where each worker is responsible for finalizing the cell phone board and putting it on the belt that runs between the counters (Figure 1). Although the type of layout described here suggests that the tasks are not monotonous, in this case they are deemed to be monotonous because there are very few technical actions to be performed.

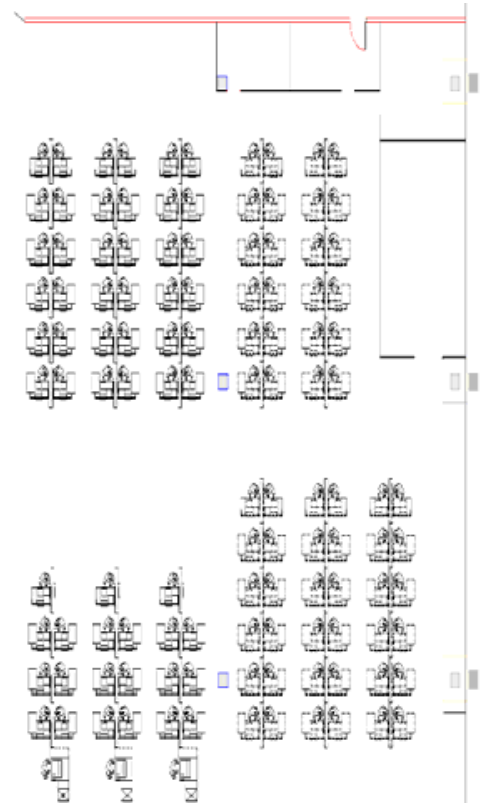

Figure 1. Workstations layout

\section{Approach and results}

The participatory ergonomics program followed in this intervention and described in this paper consisted of 5 stages: 1 . Initiative; 2. Problem identification; 3. Selection of solution; 4. Implementation and 5. Evolution [9]. This interventional study followed the participatory ergonomic stages in the following way:

\subsection{Stage 1 - Initiative}

According to [5], the initiative may arise from the occupational health department of the company. According to [7], the initiative may also come from the workers themselves or from their union. In the present study, the initiative was generated by the workers themselves during unstructured interviews with the ergonomist during an ergonomic evaluation of their workstations. It should be noted that these ergonomic evaluations and interviews are standard because they are part of the Ergonomics Program at the company which participated in this study. 


\subsection{Stage 2 - Problem identification}

This phase is deemed crucial for specifying and understanding the problem $[2,4]$. The problem was identified after the ergonomic evaluation which, at first, found three different situations that could be triggering the neck pain reported by the workers:

a) Many of the workers examined do not adjust the height of their work/task counters; b) neck flexion occurs in varying degrees among individual operators, and this means that some workers flex their necks more than others, related to the demands of the activity, to the modus operandi and the nonadjustment of the height of the counter; c) although the counters do meet the various anthropometric dimensions of workers, extra counter support is needed to facilitate precision tasks when using the screwdriver and soldering iron, as shown in Figures 2 and 3.

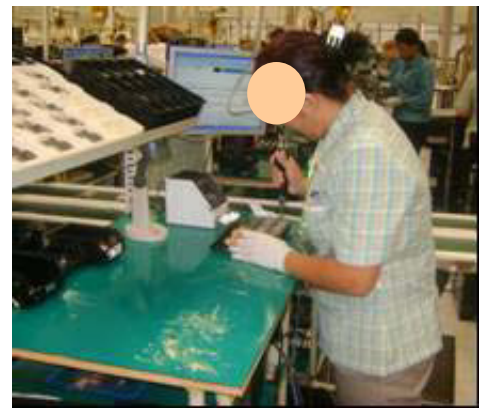

Figure 2. Posture when screwing (before ergonomic device)

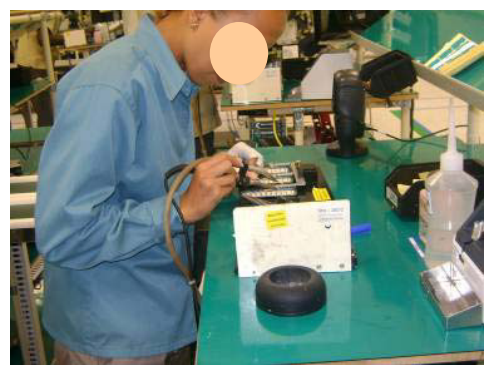

Figure 3. Posture when soldering (before ergonomic device)

Prior to the intervention, RULA was used in order to quantify the problem using direct observation of the postures, photographs and unstructured interviews with workers. The resulting RULA scores were:
Table 2

RULA Scores prior to intervention

\begin{tabular}{l|l|}
$\begin{array}{l}\text { Action Level 3 - for } \\
\text { the posture adopted } \\
\text { when screwing (Figure } \\
2)\end{array}$ & $\begin{array}{l}\text { Score of } 5 \text { for the right side assess- } \\
\text { ment, indicating the need to intro- } \\
\text { duce changes soon. }\end{array}$ \\
$\begin{array}{l}\text { Action Level 3 - for } \\
\text { the posture adopted } \\
\text { when soldering (Fig- } \\
\text { ure3) }\end{array}$ & $\begin{array}{l}\text { Score of } 6 \text { for the right side assess- } \\
\text { ment, indicating the need to intro- } \\
\text { duce changes fairly soon. } \\
{[3]}\end{array}$ \\
\hline
\end{tabular}

\subsection{Stage 3 - Selection of a Solution}

After identifying the problem in stage 2, an ergonomic device ("small counter") was developed. Its purpose was to reduce neck flexion in the tasks of screwing and soldering. It was found that the screwing tasks were best performed on a horizontal surface and the soldering task would benefit from a sloped counter, as this slope would be encourage more upright neck postures and more neutral positions of shoulders, arms and wrists. Taking these facts into account plus the fact that there were few financial resources for the development of an ergonomic device, this device - the first prototype of the small counter - was produced with pieces of PVC pipe and MDF boards (all of which could be found in the company waste). Prototype 1 allows the worker to adjust the inclination of the small counter by pushing a lever to position it horizontally (Figure 4) or in a sloped position (Figure 5).

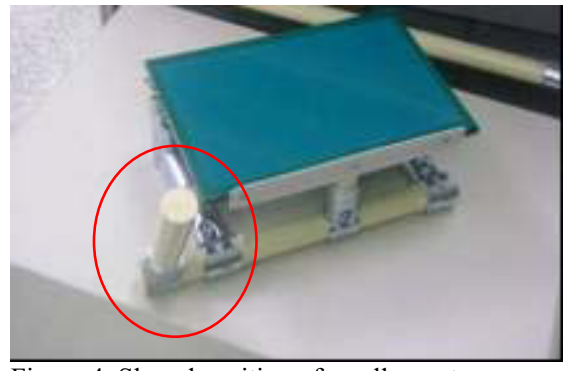

Figure 4. Sloped position of small counter

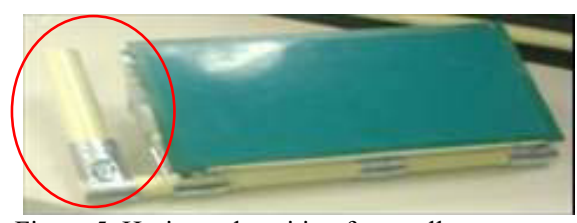

Figure 5. Horizontal position for small counter

Prototype 1 solved the problem of the neck angle. However, in any intervention, it is extremely impor- 
tant to test any device in real working situations [7] and to re-evaluate the outcome. As suggested in the literature, an evaluation of prototype 1 was carried out through unstructured interviews with 28 female workers who used the ergonomic device (prototype 1) for at least 2 hours a week on the cell phone board assembly line. All 28 workers reported an improvement in the posture of the neck, but discomfort in the forearm from resting them on the new counter, due to a raised edge at the front, which was necessary to prevent the jig from slipping down when the small counter was inclined, as shown in Figure 6.

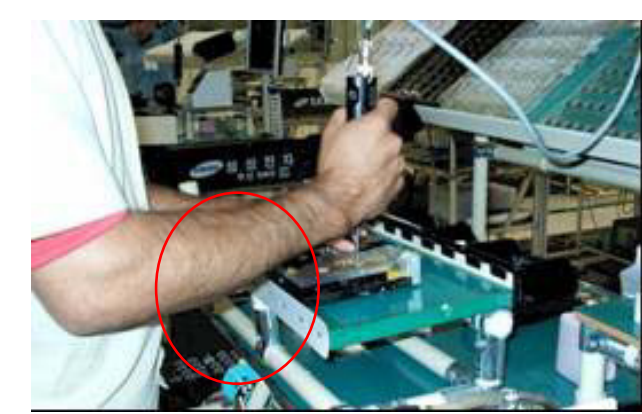

Figure 6 . Prototype 1, with raised edge at the front causing forearm discomfort.

Even though the concept of comfort is subjective and there is no universally accepted definition of comfort [6], one should never disregard the opinion of workers in a participatory approach developing an ergonomic device. Additionally, compression points may create new ergonomic hazards for the workers. Therefore, the reports from the workers who tested the device were taken into consideration and prototype 2 was developed. The difference in prototype 2 from prototype 1 was in the front cut, whose raised edge had been removed from where the forearms rest to avoid discomfort and compression points as shown in Figure 7. The development cost of the small counter was U\$9.63 dollars per unit.

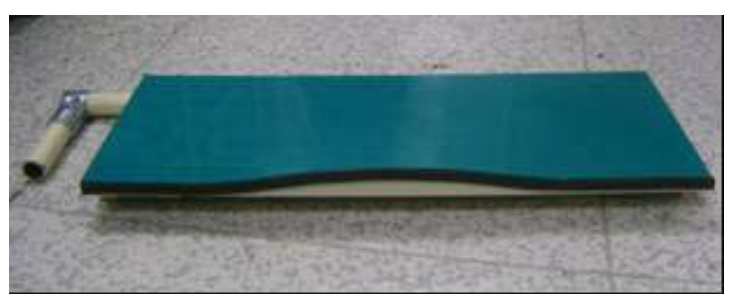

Figure 7. Small counter without raised edge on forearm rest.

\subsection{Stage 4 - Implementation}

The workers were given individual guidance by the ergonomist on how to use the small counter. Prototype 2 was tested and accepted by the 28 operators and will be implemented in all workstations in the assembly line of the company. Approximately 215 professionals will now have the benefits of an improved workstation. The postures adopted while using the new prototype 2 small counter device are better than prior to the intervention, as shown in Figures $8,9,10$ and 11 .

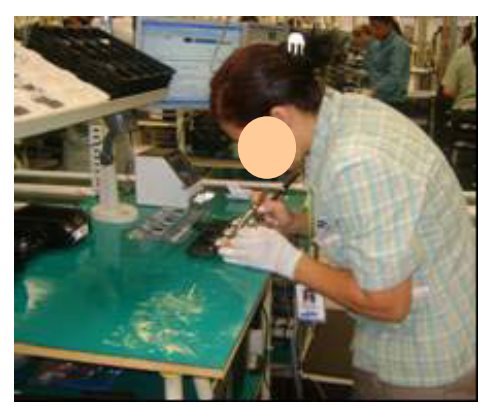

Figure 8. Posture when soldering (before ergonomic device)

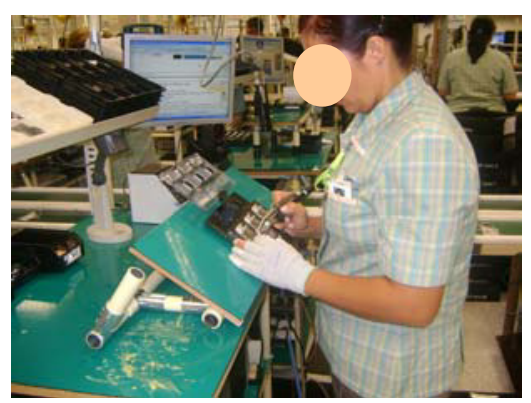

Figure 9. Posture when soldering (after ergonomic device)

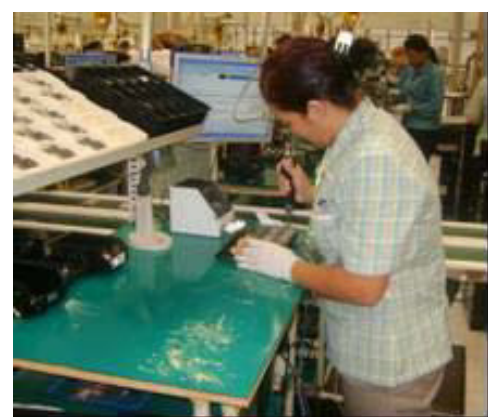

Figure 10. Posture when screwing (before ergonomic device) 


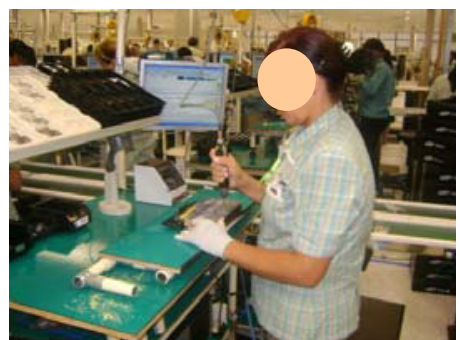

Figure 11. Posture when screwing (after ergonomic device)

Improvement in the worker's postures was verified by means of applying RULA to assess a worker using the small counter using prototype 2 . The results were:

Table 3

RULA Scores after intervention

\begin{tabular}{|l|l|}
\hline $\begin{array}{l}\text { Action Level 1 - for the } \\
\text { posture adopted when } \\
\text { screwing (Figure 8) }\end{array}$ & $\begin{array}{l}\text { Score of 2 for the right side } \\
\text { assessment, indicating that the } \\
\text { posture is acceptable if not } \\
\text { maintained for long periods of } \\
\text { time. }\end{array}$ \\
\hline $\begin{array}{l}\text { Action Level 2 - for the } \\
\text { posture adopted when } \\
\text { soldering (Figure 9) }\end{array}$ & $\begin{array}{l}\text { Score of 3 indicates that new } \\
\text { studies are needed and it may be } \\
\text { necessary to introduce changes. } \\
{[3]}\end{array}$ \\
\hline
\end{tabular}

\subsection{Stage 5 - Evaluation}

According to [4], feedback gained from each phase is essential for correcting and modifying the design process, if necessary. Changes in the original ergonomic device (prototype1) were performed and resulted in prototype 2 . This tested intervention will be implemented for the entire cell phone board assembly workforce. New interviews will be conducted with workers who have not yet tested the device in order for the evolution of results to iteratively take place with potential updates to the design of the intervention.

While the concept of comfort was instinctively taken into account by the workers when deciding to employ the new workstation, which resulted in fewer complaints of neck pain; $10 \%$ of the workers worried about the productivity factor. This group reported that the small counter was too large and took up all of the counter surface, which made it difficult to place the other components (table 4).
Table 4

Overall results

\begin{tabular}{|l|l|}
\hline \multicolumn{2}{|c|}{ Overall results } \\
\hline $\begin{array}{l}\text { Percentage of workers using } \\
\text { the new workstation is }\end{array}$ & $90 \%$ \\
\hline $\begin{array}{l}\text { The new work station is pre- } \\
\text { ferred by }\end{array}$ & $\begin{array}{l}\text { Workers between } 165 \mathrm{~cm} \text { and } \\
173 \mathrm{~cm} \text { tall }\end{array}$ \\
\hline Comfort is improved by & $\begin{array}{l}\text { Tilting the small counter dur- } \\
\text { ing soldering; and making it } \\
\text { higher and horizontal during } \\
\text { screwing. }\end{array}$ \\
\hline $\begin{array}{l}\text { Neck complaints are reduced } \\
\text { by }\end{array}$ & $\begin{array}{l}\text { The decrease in the flexing } \\
\text { angle of the neck and of ab- } \\
\text { duction of the shoulders. }\end{array}$ \\
\hline
\end{tabular}

\section{Discussion}

This study is an example of how participatory ergonomics can contribute to practical, inexpensive solutions that meet the needs of the worker and reduce neck complaints. Support from the management, from the Environment, Health and Labor Security, from the employees who voluntarily tested the prototypes and in particular from the maintenance technician who developed the device with us was crucial for this study and change to happen. Within our research, the main change was the posture of the workers, which can be observed in the pictures. The small counter intervention allowed workers to adopt better working postures during the screwing and soldering tasks. RULA also confirms the visible difference in postures by decreasing the scores for screwing and soldering from 5 and 6 before intervention to 2 and 3 after intervention, respectively [3]. Workers who tested Prototype 1 gave positive feedback, which made us modify the design of the small counter in terms of reducing its sharp edges/compression points for the forearm. The same workers tested Prototype 2 and made more suggestions, which allowed us to develop two small counters, with different lengths (one being $23 \mathrm{~cm} \times 20 \mathrm{~cm}$ and the other being $36 \mathrm{~cm} \mathrm{x}$ $20 \mathrm{~cm}$ ); this makes it possible for them to be adjusted to the different jig sizes and not take up too much space on the workstation, which should satisfy those $10 \%$ of workers concerned that the size of the counter might reduce productivity. 
The good acceptance of this ergonomic device by the workers has encouraged us to implement small counters for workers in other areas within the company, thus benefiting over 1,000 employees. It has also compelled us to establish a partnership with companies specialized in developing ergonomic products so they can manufacture the small counter on a large scale for similar industries.

\section{Conclusion}

All phases in the participatory ergonomics approach described by [9] are used in this approach (an initiative, a problem identification, a selection of solutions, an implementation and an evaluation). This approach resulted in the reduction of ergonomic complaints. Perhaps the most crucial element in the process was the fact that the workers took the initiative, which resulted in a better work place according to $90 \%$ of the worker population.

In summary, it is important to note that, in this first phase, we did not aim at measuring productivity improvements. Nonetheless, when informally asking workers about this factor, we were informed that there was not significant reduction in productivity. Thus, we are expanding our research to start manufacturing the final prototype through a partnership with a company that makes ergonomic accessories. This way we are able to demonstrate that participatory ergonomics is a great ally in improving comfort issues within the work environment, facilitating the productive process and preventing musculoskeletal disorders.

\section{References}

[1] T. Bosch, M. de looze \& J. van Dieen, Development of fatigue and discomfort in the upper trapezius muscle during light manual work. Ergonomics 50, 2007, pp. 161-177.

[2] T. J. Howard, S. J. Culley \& E. Dekoninck. Describing the creative design process by the integration of engineering design and cognitive psychology literature. Design Studies, 29, 2008, pp. 160-180.

[3] L. McAtamney \& E. N. Corlett. RULA: A survey method for the investigation of work-related upper limb disorders. $A p$ plied Ergonomics, 24 (2), 1993, pp. 91-99.

[4] S. B. Niku. Creative Design of Products and Systems. Hoboken, NJ: Wiley, 2009.

[5] L. Patry, M. Cote \& I. Kuorinka. Participatory ergonomics of two workstations : Warehouse employees and police officers. In: Y. Quéinnec and F. Daniellou, eds., Designing for Everyone: Proceedings of the 11th Congress of the International Ergonomics Association, Vol. II, London: Taylor \& Francis, 1991, pp.1747-1749.

[6] J. Van der Linden. Ergonomia e Design: prazer, conforto e risco no uso de produtos. Porto Alegre: Editora UniRitter, 2007.

[7] P. Vink, A. S. Imada, and K. J. Zenk. Defining stakeholder involvement in participatory design processes. Applied Ergonomics, 39, 2008, 519-526.

[8] P. Vink \& M.A.J. Kompier. Improving office work: a participatory ergonomics experiment in a naturalistic setting. Ergonomics 40, 1997, pp. 439-449.

[9] P. Vink, E.A.P. Koningsveld \& J.F.M Molenbroek. Positive outcomes of participatory ergonomics in terms of greater comfort and higher productivity. Applied Ergonomics 37, 2006, pp. 537-546.

[10] K. Walker-Bone \& C. Cooper. Hard work never hurt anyone: or did it? Annals of the Rheumatic Diseases 64, 2005, pp. 1391-1396. 